\title{
Nutritional composition of school meals serving children from 7 to 36 months of age in municipal day-care centres in the metropolitan area of Curitiba, Paraná, Brazil
}

\author{
Anabelle Retondario ${ }^{1}$, Débora Letícia Frizzi Silva ${ }^{2}$, Silvana Magalhães Salgado ${ }^{3}$, \\ Márcia Aurelina de Oliveira Alves ${ }^{4}$ and Sila Mary Rodrigues Ferreira ${ }^{4 *}$ \\ ${ }^{1}$ Graduate Program of Food and Nutrition Safety, Health Sciences Sector, Federal University of Paraná, Av. Pref. Lothário \\ Meissner, 632, Botanical Garden, 80.210-170 Curitiba, Paraná, Brazil \\ ${ }^{2}$ Department of Nutrition, Health Sciences Sector, Federal University of Paraná, Av. Pref. Lothário Meissner, 632, Botanical \\ Garden, 80.210-170 Curitiba, Paraná, Brazil \\ ${ }^{3}$ Graduate Program of Nutrition, Health Sciences Center, Federal University of Pernambuco, Av. Prof. Moraes Rego, s/n, \\ University City, 50.670-901 Recife, Pernambuco, Brazil \\ ${ }^{4}$ Department of Nutrition, Graduate Program of Food and Nutrition Security, Health Sciences Sector, Federal University of \\ Paraná, Av. Pref. Lothário Meissner, 632, Botanical Garden, 80.210-170 Curitiba, Paraná, Brazil
}

(Submitted 9 July 2015 - Final revision received 27 February 2016 - Accepted 14 March 2016)

\section{Abstract}

The Brazilian National School Feeding Program (PNAE) seeks to meet student's nutritional needs during the period they remain in school. This study aimed to determine the nutritional composition of meals provided in municipal day-care centres serving children of 7-11 months (group A) and 12-36 months (group B) of age and to compare observed values with the PNAE's and dietary reference intakes' (DRI) recommendations. This cross-sectional study was conducted in 4 day-care centres in the metropolitan area of Curitiba, Paraná, Brazil, between June and November 2013. Food samples of six daily meals were collected during 20 non-consecutive days, totalling 120 samples. For each meal, average served and consumed portions were submitted for laboratory analysis of moisture, ash, proteins, lipids, carbohydrates, dietary fibre, $\mathrm{Na}, \mathrm{Ca}$ and $\mathrm{Fe}$ and compared with the PNAE's and DRI's values. No statistically significant difference was found between age groups $(P=0.793)$ regarding portion sizes and nutritional composition. The same menu was offered to both groups in $95 \%$ of the meals $(n 114)$, although the groups' nutritional needs were different. For group A, served meals met PNAE's recommendations for energy, carbohydrates, proteins, $\mathrm{Na}$ and $\mathrm{Ca}$ content, and consumed portions provided $70 \%$ of the nutritional needs for carbohydrates, proteins and Ca. For group B, served portions complied with the PNAE's values for proteins, $\mathrm{Na}$ and $\mathrm{Ca}$. Proteins and $\mathrm{Na}$ reached $70 \%$ of the nutritional needs when consumed food was evaluated. School feeding in day-care centres partially meet PNAE's guidelines and children's nutritional requirements, contradicting the primary objective established by the national programme.

Key words: School feeding: Food analyses: RDA: Child day-care centres

Day-care centres are educational institutions that serve children younger than 3 years of age. Their main purpose is to promote a child's cognitive development and to support families with working parents ${ }^{(1-3)}$.

Families of children attending day-care facilities expect such institutions to secure their children's right to a healthy diet that is appropriate to the particular needs of each age group ${ }^{(2)}$. The food provided in a school environment should improve the child's ingestion of energy and nutrients ${ }^{(2,4)}$, as adequate nutrition in the early years guarantees proper growth and development, cooperating for a lifetime of improved health ${ }^{(5)}$. The National School Feeding Program (Portuguese acronym,
PNAE) is a Brazilian public policy for food and nutrition safety, responsible for appointing the necessary parameters to serve meals in day-care centres and schools. This programme determines that children staying full time in educational institutions $(7 \mathrm{~h} / \mathrm{d})$ must have at least $70 \%$ of the children's nutritional needs met by a school feeding policy ${ }^{(6,7)}$.

Previous research has measured the amounts of energy and nutrients offered by schools through methodologies based on food composition tables ${ }^{(8-10)}$ as well as qualitative approaches $^{(11-13)}$. The use of these tools may be appropriate for diet planning and evaluation. However, it is fragile, as a complete food composition table covering variations in recipes,

Abbreviations: DRI, dietary reference intakes; PNAE, National School Feeding Program.

* Corresponding author: Dr S. M. R. Ferreira, fax +55 413360 4133, email sila.ufpr@gmail.com 
ingredients and cooking procedures cannot be currently found in Brazil. Therefore, when laboratory analysis methods and standardised techniques recommended by organisations such as AOAC International (formerly known as Association of Official Analytical Chemists) and the Adolfo Lutz Institute (IAL) are used to determine meals' nutritional composition, biased sources are eliminated from the food composition tables, such as those caused by ingredients replaced during food preparation, vegetable seasonality or type of animal feeding ${ }^{(14-16)}$. Therefore, one of the main advantages in performing laboratory analyses, as opposed to the use of composition tables, is to provide a measure of the actual amount of nutrients in food samples.

Considering the important role of day-care facilities in guaranteeing the nutritional needs of children attending full time, the objective of this study was to determine, through laboratory analysis, the nutritional composition of both served and consumed meals in municipal day-care centres of the metropolitan area of Curitiba, Paraná, Brazil, and to evaluate whether it complies with the minimum parameters established by the PNAE and the dietary reference intakes (DRI) values for each age group.

\section{Methods}

\section{Sampling}

A cross-sectional, analytical and observational study was performed in Colombo, Paraná, Brazil. Out of the thirty-eight municipal day-care facilities serving children from 7 to 36 months of age, four were selected through stratified cluster sampling and random drawings proportional to the number of children enrolled. During the study's period, the city served a total of 816 children, distributed among geographical areas, or sectors: the main area, Maracanã and Guaraituba, receiving
367, 215 and 234 children, respectively. The random drawings matched the percentages of children enrolled in each sector, with 2 day-care institutions selected for the region with the largest number of enrolled children, the main area. Therefore, each of the three sectors corresponded to 48, 29 and $23 \%$, respectively, of the total number of children enrolled. A total of 120 samples were collected and analysed in triplicate for eight different parameters, resulting in the performance of 2880 laboratory analyses. Thus, selecting a larger number of schools was not effective, because of the high costs and complexity involved in these laboratory analyses.

For $20 \mathrm{~d}$, the six daily served meals were collected on 5 non-consecutive days from each day-care centre. Considering that each institution had the same weekly menu, as prescribed by a nutritionist, this sampling method represented the weekly menu offered by each institution and the monthly menu provided by the city. A total of 120 meal samples were collected (6 meals $/ \mathrm{d} \times 5 \mathrm{~d} /$ week $\times 4$ day-care centres $=120$ samples). A summary of the methodology is provided in Fig. 1.

\section{Ethical aspects}

This study's project was approved by the Committee on Ethics in Research in Human Beings of the Health Sciences Sector of the Universidade Federal do Paraná (Portuguese acronym, UFPR), CAAE no. 11460612.8.0000.8.0000.0102, and authorised by the Department of Education, Culture and Sport of the city.

\section{Samples collection and preparation}

At food distribution, samples of approximately $300 \mathrm{~g}$ were collected, stored in labelled polypropylene packages, refrigerated at a temperature of $7-10^{\circ} \mathrm{C}$ and transported to the Food Analysis Laboratory of the Nutrition Department of UFPR for preparation and analysis. Food samples of solid or thick consistency, such

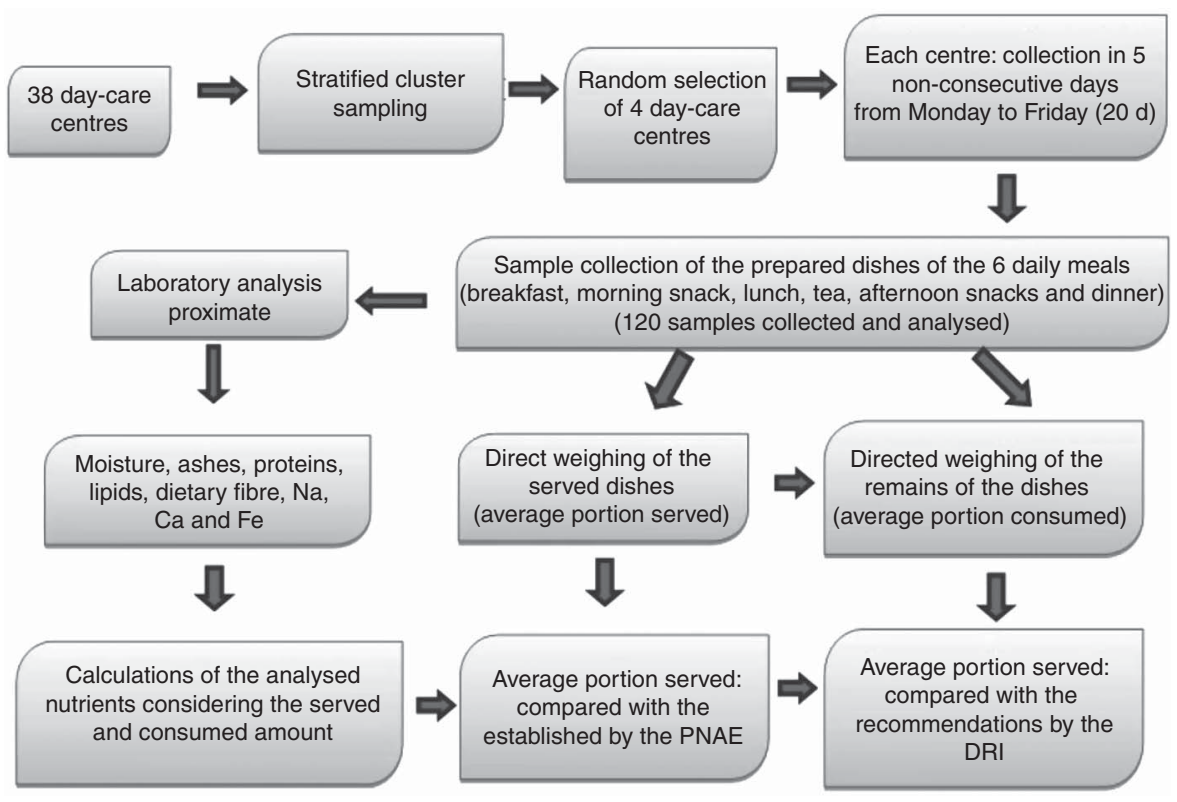

Fig. 1. Research flow chart. PNAE, National School Feeding Program; DRI, dietary reference intakes. 
as rice, beans, meat and soups were dehydrated at $40-55^{\circ} \mathrm{C}$ for $24-48 \mathrm{~h}$ in a drying oven with air circulation until they reached humidity levels $<10 \%{ }^{(14)}$. Liquid samples such as milk, porridge and tea were analysed from the humid base.

\section{Determination of the average served and consumed and food waste}

The portion size averages were determined by direct weighing ${ }^{(17)}$ of dishes served. At least six dishes ready for consumption were weighed to compute the mean of portions served to the children, separated by age group: children from 7 to 11 months of age (group A) and children from 12 to 36 months of age (group B). After ingestion of meals, the food that was not consumed was weighed from at least six dishes to obtain the mean of the ingested portion. Thus, we obtained an average served portion and an average consumed portion for each of the 120 meals included in this study.

From the average served and consumed portions of each of the 120 meals, we obtained the average rest-ingestion, according to the following equation:

$$
\mathrm{RI}=\left(\mathrm{DA} \times 100 / \mathrm{PS}_{1}\right),
$$

where RI is the average rest-ingestion ( $\mathrm{g}$ ), DA the average waste $(\mathrm{g})$ and $\mathrm{PS}_{1}$ the average portion served $(\mathrm{g})$.

$$
\mathrm{DA}=\left(\mathrm{PS}_{1}-\mathrm{PC}_{1}\right),
$$

where $\mathrm{PS}_{1}$ is the average portion served $(\mathrm{g})$ and $\mathrm{PC}_{1}$ the average portion consumed $(\mathrm{g})$

\section{Chemical composition of the samples and total energy values}

A chemical composition analysis for each meal was performed through proximate analysis of the collected samples $(n 120)$ for determination of moisture $(\mathrm{g} / 100 \mathrm{~g})$, ash $(\mathrm{g} / 100 \mathrm{~g})$, proteins $(\mathrm{g} / 100 \mathrm{~g})$, lipids $(\mathrm{g} / 100 \mathrm{~g})$ and dietary fibre $(\mathrm{g} / 100 \mathrm{~g})$, in accordance with the methodology recommended by the Official Methods of Analysis of AOAC International (2000). Na $(\mathrm{mg} / 100 \mathrm{~g}), \mathrm{Ca}(\mathrm{mg} / 100 \mathrm{~g})$, and $\mathrm{Fe}(\mathrm{mg} / 100 \mathrm{~g})$ were analysed according to IAL's methodology ${ }^{(16)}$. Carbohydrates (g/100 g) were calculated by difference ${ }^{(16)}$. The total energy value $(\mathrm{J}(\mathrm{kcal}))$ was computed according to Atwater's conversion ${ }^{(18)}$. In order to convert kilocalories into joules (J), we multiplied results by 4186 . The use of local recipes was not necessary as differences in formulations were identified by laboratory techniques.

\section{Comparative analysis between served nutrients and National School Feeding Program's official parameters}

The average content of each nutrient offered by the school feeding programme was computed as a simple average of the nutrient's daily supply, as expressed by the following equation:

Average supply of nutrient $y=\sum \frac{\text { nutrient } y \text { supplied in the } 20 \mathrm{~d}}{20}$.

Average values were calculated with the results obtained from the physicochemical analyses (energy, carbohydrates, proteins, lipids, Dietary fibre, $\mathrm{Na}, \mathrm{Ca}$ and $\mathrm{Fe}$ ) and compared with each nutrient's recommended value advocated by the PNAE $^{(6)}$ for each age group (Table 2).

\section{Comparative analysis between consumed nutrients and the Institute of Medicine's dietary reference intake values}

A mean content value for each actually consumed nutrient was computed as the simple average of the nutrient's daily intake, as shown in the following equation:

Average consumption of nutrient $y$

$$
=\sum \frac{\text { nutrient } y \text { consumed in the } 20 \mathrm{~d}}{20} \text {. }
$$

Averages were calculated with the results of the physicochemical analysis of actually consumed meals and were compared with the DRI ${ }^{(19-22)}$, considering that the school feeding programme must provide at least $70 \%$ of its full-time students' nutritional needs ${ }^{(6)}$ (Table 1). Energetic values were computed considering the recommended macronutrient energy values for each age group ${ }^{(20-21)}$.

\begin{tabular}{|c|c|c|c|c|c|c|}
\hline \multirow[b]{2}{*}{ Analysed parameter } & \multicolumn{3}{|c|}{ Group A (7-11 months) } & \multicolumn{3}{|c|}{ Group B (12-36 months) } \\
\hline & PNAE* $^{*}$ & DRI† & $70 \% \mathrm{DRI}$ & $\mathrm{PNAE}^{*}$ & DRI† & $70 \% \mathrm{DRI}$ \\
\hline Energy (kJ/kcal) & $1882 \cdot 80 / 450 \cdot 00$ & $2905.08 / 694.00 \ddagger$ & $2033.56 / 485.80$ & $2928 \cdot 80 / 700 \cdot 00$ & $3420.55 / 817 \cdot 10 \ddagger$ & $2394.39 / 572.00$ \\
\hline Carbohydrates (g) & $73 \cdot 10$ & 95.00 & 66.50 & 114.90 & 130.00 & 91.00 \\
\hline Proteins $(\mathrm{g})$ & 14.00 & 11.00 & $7 \cdot 70$ & 21.90 & 13.00 & $9 \cdot 10$ \\
\hline Lipids (g) & 11.30 & 30.00 & 21.00 & $17 \cdot 50$ & $27 \cdot 20 \S$ & $19 \cdot 10$ \\
\hline Dietary fibre $(\mathrm{g})$ & - & - & - & $13 \cdot 30$ & 19.00 & $13 \cdot 30$ \\
\hline $\mathrm{Na}(\mathrm{mg})$ & $1400 \cdot 00 \|$ & _- & _- & 1400.00 & $1500 \cdot 00$ & 1050.00 \\
\hline $\mathrm{Ca}(\mathrm{mg})$ & 189.00 & $260 \cdot 00$ & 182.00 & 350.00 & 700.00 & 490.00 \\
\hline $\mathrm{Fe}(\mathrm{mg})$ & $7 \cdot 70$ & 11.00 & $7 \cdot 70$ & 4.90 & 7.00 & 4.90 \\
\hline
\end{tabular}

Table 1. Recommendations of nutrients established by the National School Feeding Program (PNAE) per day for full-time period, nutritional needs recommended by the Institute of Medicine, and $70 \%$ of the nutritional needs, according to the age group

DRI, dietary reference intakes; -, values not established for the age group.

${ }^{*}$ Brazil Ministry of Education and Culture ${ }^{(6)}$.

† RDA for $\mathrm{Fe}^{(19)}$, carbohydrates for group $\mathrm{B}^{(20)}$, proteins ${ }^{(20)}$ and $\mathrm{Ca}$ for group $\mathrm{B}^{(22)}$; estimated energy requirements for energy value ${ }^{(20)}$; tolerable upper intake levels for $\mathrm{Na}^{(21)}$. adequate intakes for carbohydrates for group $A^{(20)}$, Ca for group $A^{(22)}$ and food fibres for group $B^{(20)}$.

$\ddagger$ Value calculated from the energy from macronutrients recommended for the age group.

$\S$ Value obtained from $30 \%$ of the total energy content calculated for the age group.

II Stipulated maximum value for $\mathrm{Na}$ in school feeding. 


\section{Statistical analysis}

Data sets were organised using Microsoft Excel $^{\circledR}$ spreadsheets, and statistical analysis were performed using IBM SPSS ${ }^{\circledR}$ Statistics for Windows, version $19.0^{(23)}$. Descriptive statistics were produced with a distribution of frequencies, and Student's $t$ and Mann-Whitney tests were run to compare served and consumed amounts of nutrients. The level of significance was $\alpha=0.05$ for all analyses.

\section{Results}

The portion size served during the six meals was, on average, $788 \mathrm{~g} / \mathrm{d}$; however, only $607 \mathrm{~g} / \mathrm{d}$ on average was consumed, generating a refusal of $181 \mathrm{~g} /$ student per $\mathrm{d}$ and an average restingestion of $23 \%$. There was no significant difference in offered portion sizes $(\mathrm{g})$ between groups A and B $(P=0.793)$, except for lunch meals in the second school semester $(P=0 \cdot 047)$.

The most frequently served meals in day-care centres are described in Table 2. Porridge was served as a breakfast meal on all of the $20 \mathrm{~d}$ of evaluation, and as an afternoon snack in $45 \%$ of the evaluated days ( $n 9)$. At lunchtime, rice, beans and meat (beef or chicken) were served on $75 \%$ of the days ( $n 15$ ), and at dinner pasta, soup and potatoes, with meat representing the most frequent meal, offered on $85 \%$ of the evaluated days (n 17).
The average daily amount of nutrients served for both group A (7-11 months) and group B (12-36 months) children and a comparison with the parameters established by the PNAE are shown in Table 3. The served nutritional composition met PNAE's parameters for energy, carbohydrates, proteins, $\mathrm{Na}$ and $\mathrm{Ca}$ in group $\mathrm{A}$ and proteins, $\mathrm{Na}$ and $\mathrm{Ca}$ in group $\mathrm{B}$. Considering $\mathrm{Na}$ levels, the recommended amount sets a maximum value for children. Thus, a percentage $<100 \%$ of the recommended value meets the criteria. For all other nutrients, the current legislation appoints the minimum values that must be fulfilled by the school feeding system.

A comparison by age group of the average daily amount of served and consumed nutrients is presented in Table 4. The average nutritional composition of offered meals presented statistical differences when compared with the consumed meals $(P<0.05)$, except for lipids in group A and dietary fibre, Ca and Fe in both groups, especially with regard to energy amounts.

Table 5 presents a comparison between consumed nutrients and Institute of Medicine's (IOM) recommended values for children of 7-36 months of age. For group A children, a minimum of $70 \%$ of their nutritional needs was met by the school feeding system with regard to carbohydrates, proteins and $\mathrm{Ca}$. For that age group, fibre and $\mathrm{Na}$ reference values do not exist. The nutritional needs of group B children were satisfied with respect to proteins and $\mathrm{Na}$ content; the school feeding programme provided $<50 \%$ of the DRI for lipids, fibre and Fe.

Table 2. Most frequently served meals by the school feeding for groups $A$ and $B$

(Numbers and percentages)

\begin{tabular}{|c|c|c|c|}
\hline \multirow[b]{2}{*}{ Foods } & \multirow[b]{2}{*}{ Meal } & \multicolumn{2}{|c|}{ Frequency } \\
\hline & & $n$ & $\%$ \\
\hline \multirow[t]{2}{*}{ Porridges (powdered milk, water, starch and refined sugar) } & Breakfast & 20 & 100 \\
\hline & Afternoon snack & 9 & 45 \\
\hline \multirow[t]{2}{*}{ Bread (no side dishes) } & Breakfast & 1 & 5 \\
\hline & Morning snack & 2 & 10 \\
\hline \multirow[t]{2}{*}{ Bread with margarine } & Breakfast & 1 & 5 \\
\hline & Morning snack & 2 & 10 \\
\hline \multirow[t]{2}{*}{ Biscuits } & Morning snack & 4 & 20 \\
\hline & Afternoon snack & 4 & 20 \\
\hline \multirow[t]{2}{*}{ Reconstituted concentrated juice } & Morning snack & 1 & 5 \\
\hline & Afternoon snack & 2 & 10 \\
\hline Strawberry yogurt & Morning snack & 1 & 5 \\
\hline \multirow[t]{2}{*}{ Fruits (banana, peeled apple and watermelon) } & Morning snack & 10 & 50 \\
\hline & Afternoon snack & 2 & 10 \\
\hline Reconstituted powdered milk sweetened with refined sugar & Afternoon snack & 1 & 5 \\
\hline Milk with chocolate powder sweetened with refined sugar & Afternoon snack & 1 & 5 \\
\hline Cake & Afternoon snack & 1 & 5 \\
\hline Jelly & Afternoon snack & 2 & 10 \\
\hline Sago & Afternoon snack & 1 & 5 \\
\hline Sweet rice & Afternoon snack & 1 & 5 \\
\hline Teas (fennel, mate, chamomile, mint, chamomile with mint) & Tea after lunch & 19 & 95 \\
\hline Chicken & Lunch & 5 & 25 \\
\hline Beef & Lunch & 10 & 50 \\
\hline Rice and beans & Lunch & 15 & 75 \\
\hline Soups with meat (chicken or beef) & Lunch & 5 & 25 \\
\hline Vegetables (cauliflower, carrots, tomatoes, beetroots, onions, chayote or kale) & Lunch & 14 & 70 \\
\hline Pasta soup and/or potato with meat (chicken or beef) & Dinner & 17 & 85 \\
\hline Pasta soup and/or potato without meat & Dinner & 1 & 5 \\
\hline Instant noodle soup & Dinner & 2 & 10 \\
\hline
\end{tabular}

Breakfast was served from 07.30 to 08.30 hours. Morning snack was served from 09.30 to 10.30 hours. Lunch was served from 11.00 to 12.00 hours. Tea was served after lunch (around noon). Afternoon snack was served from 13.30 to 14.30 hours and dinner from 16.00 to 16.30 hours. 
Table 3. Average daily amount of nutrients provided to the children and comparison with the parameters established by the National School Feeding Program (PNAE)

\begin{tabular}{|c|c|c|c|c|c|c|c|c|c|}
\hline \multirow[b]{2}{*}{ Analysed parameter } & \multicolumn{4}{|c|}{ Group A (7-11 months) } & \multicolumn{5}{|c|}{ Group B (12-36 months) } \\
\hline & $\begin{array}{l}\text { Average daily } \\
\text { amount served } \\
(20 \mathrm{~d})\end{array}$ & SD & $\begin{array}{l}\text { Values } \\
\text { established by } \\
\text { the PNAE* }\end{array}$ & $\begin{array}{c}\% \text { of nutrient provided in relation } \\
\text { to the recommended by the } \\
\text { PNAE }\end{array}$ & $\begin{array}{l}\text { Average daily } \\
\text { amount served } \\
(20 \mathrm{~d})\end{array}$ & SD & $\begin{array}{l}\text { Values } \\
\text { established by } \\
\text { the PNAE* }\end{array}$ & $\begin{array}{l}\% \text { of nutrient provided in relation } \\
\text { to the recommended by the } \\
\text { PNAE }\end{array}$ & $\begin{array}{c}P \text { value supplied } \\
\text { to groups } A \text { and } \\
B \dagger\end{array}$ \\
\hline $\operatorname{VET}(\mathrm{kJ} / \mathrm{d}$ or $\mathrm{kcal} / \mathrm{d}) \ddagger$ & $2348 \cdot 35 / 561 \cdot 27$ & $150 \cdot 36$ & $1882 \cdot 80 / 450 \cdot 00$ & $124 \cdot 73$ & $2448 \cdot 27 / 585 \cdot 18$ & 123.39 & $2928 \cdot 80 / 700 \cdot 00$ & 83.59 & $0.327^{\lambda}$ \\
\hline Carbohydrates $(\mathrm{g} / \mathrm{d}) \ddagger$ & 99.32 & 25.71 & $73 \cdot 10$ & $135 \cdot 87$ & 100.96 & 22.81 & 114.90 & 87.87 & $0.585^{\psi}$ \\
\hline Proteins $(\mathrm{g} / \mathrm{d}) \ddagger$ & $23 \cdot 28$ & $8 \cdot 30$ & 14.00 & $166 \cdot 29$ & 24.03 & $6 \cdot 34$ & 21.90 & $109 \cdot 73$ & $0.184^{\psi}$ \\
\hline Lipids $(\mathrm{g} / \mathrm{d}) \ddagger$ & $7 \cdot 87$ & 3.72 & $11 \cdot 30$ & 69.65 & $9 \cdot 47$ & 3.43 & 17.50 & 54.11 & $0.721^{\Psi}$ \\
\hline Dietary fibre $(g / d) \neq \S$ & $10 \cdot 41$ & $5 \cdot 61$ & - & - & 10.09 & 4.81 & $13 \cdot 30$ & $75 \cdot 87$ & $0.690^{\psi}$ \\
\hline $\mathrm{Na}(\mathrm{mg} / \mathrm{d}) \|$ & 1261.92 & 321.03 & $1400 \cdot 00$ & $90 \cdot 14$ & 1251.00 & 261.74 & 1400.00 & 89.36 & $0 \cdot 201^{\psi}$ \\
\hline $\mathrm{Ca}(\mathrm{mg} / \mathrm{d}) \ddagger$ & 497.76 & 224.62 & 189.00 & 263.37 & 497.02 & 222.85 & 350.00 & 142.01 & $0.947^{\lambda}$ \\
\hline $\mathrm{Fe}(\mathrm{mg} / \mathrm{d}) \ddagger$ & $2 \cdot 35$ & 3.59 & $7 \cdot 70$ & 30.52 & $2 \cdot 26$ & 3.60 & 4.90 & $46 \cdot 12$ & $0.640^{\lambda}$ \\
\hline Served portion size (g) & $798 \cdot 31$ & $177 \cdot 04$ & - & - & $784 \cdot 11$ & 161.92 & - & - & $0.793^{\psi}$ \\
\hline
\end{tabular}

PNAE, National School Feeding Program; VET, total energy content; -, values not established for the age group.

* Brazil Ministry of Education and Culture ${ }^{(6)}$

$\dagger P$ values obtained with the comparison of average daily consumption between groups. The superscript letters on the $P$ values correspond to the statistical tests applied, according to the variable's behaviour: $\lambda$ indicates non-parametric behaviour and the use of Mann-Whitney test, whereas $\psi$ indicates that the variables presented normal distribution, having applied the Student's $t$ test.

¥ Minimum values recommended for energy offer and nutrients in school feeding.

$\S$ There are no recommended values for offer of dietary fibre for group $A$.

Stipulated maximum value for $\mathrm{Na}$ in school feeding.

Table 4. Comparison of nutrient content consumed in meals with the recommendation of the Institute of Medicine for children aged 7-11 months (group A) and 12-36 months (group B)

\begin{tabular}{|c|c|c|c|c|c|c|c|c|c|}
\hline \multirow[b]{2}{*}{ Analysed parameter } & \multicolumn{4}{|c|}{ Group A (7-11 months) } & \multicolumn{5}{|c|}{ Group B (12-36 months) } \\
\hline & $\begin{array}{c}\text { Average daily } \\
\text { consumption (20d) }\end{array}$ & SD & $\mathrm{DRI}^{*}$ & $\begin{array}{l}\% \text { of compliance in } \\
\text { relation to the needs of } \\
\text { the childrent }\end{array}$ & $\begin{array}{c}\text { Average daily } \\
\text { consumption (20 d) }\end{array}$ & SD & $\mathrm{DRI}{ }^{*}$ & $\begin{array}{l}\% \text { of compliance in } \\
\text { relation to the needs of } \\
\text { the childrent }\end{array}$ & $\begin{array}{l}P \text { value consumed } \\
\text { by groups } A \text { and } B \ddagger\end{array}$ \\
\hline VET $(\mathrm{kJ} / \mathrm{d}$ or $\mathrm{kcal} / \mathrm{d})+\S$ & $1806.15 / 431.68$ & 98.56 & $2905.08 / 694.00$ & $62 \cdot 20$ & $1827 \cdot 19 / 436 \cdot 71$ & 83.60 & $3420 \cdot 55 / 817.14 \S$ & 53.44 & $0.735^{\lambda}$ \\
\hline Carbohydrates $(\mathrm{g} / \mathrm{d}) t$ & 76.85 & 17.67 & 95.00 & 80.89 & 76.25 & 15.84 & 130.00 & 58.65 & $0.912^{\psi}$ \\
\hline Proteins $(\mathrm{g} / \mathrm{d}) \dagger$ & 17.70 & $5 \cdot 75$ & 11.00 & 160.91 & 17.76 & 4.43 & 13.00 & $136 \cdot 62$ & $0.971^{\psi}$ \\
\hline Lipids $(\mathrm{g} / \mathrm{d})+\|$ & 5.94 & 2.63 & 30.00 & 19.80 & 6.74 & 2.61 & $27 \cdot 24 \|$ & 24.74 & $0.343^{\psi}$ \\
\hline Dietary fibre $(\mathrm{g} / \mathrm{d})+\mathrm{d}$ & 7.82 & 4.16 & - & - & 7.50 & 3.63 & 19.00 & 39.47 & $0.802^{\psi}$ \\
\hline $\mathrm{Na}(\mathrm{mg} / \mathrm{d})+\uparrow$ & 959.51 & $236 \cdot 80$ & - & - & $919 \cdot 73$ & 207.84 & 1500.00 & 61.32 & $0.576^{\psi}$ \\
\hline $\mathrm{Ca}(\mathrm{mg} / \mathrm{d}) \dagger$ & 384.33 & $175 \cdot 25$ & $260 \cdot 00$ & 147.82 & 379.95 & $\begin{array}{l}201.04 \\
173.49\end{array}$ & 700.00 & 54.28 & $0.839^{\lambda}$ \\
\hline $\mathrm{Fe}(\mathrm{mg} / \mathrm{d}) \mathrm{t}$ & 1.84 & 2.85 & 11.00 & 16.73 & 1.74 & 2.86 & 7.00 & 24.86 & $0.543^{\lambda}$ \\
\hline Consumed portion size $(\mathrm{g})$ & 621.01 & $122 \cdot 51$ & - & - & $601 \cdot 16$ & 119.61 & _- & - & $0.607^{\psi}$ \\
\hline
\end{tabular}

DRI, dietary reference intakes; VET, total energy content; -, values not established for the age group

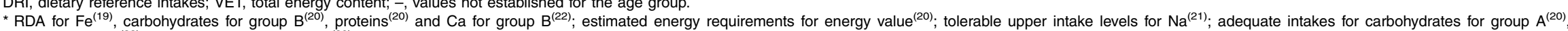
Ca for group $\mathrm{A}^{(22)}$ and dietary fibre for group $\mathrm{B}^{(20)}$.

t Were considered as adequate the nutrients that met $70 \%$ or more of the DRI of the children for VET, carbohydrates, proteins, lipids, dietary fibre, Ca and Fe and maximum $70 \%$ of DRI for Na.

$\ddagger P$ value obtained with the comparison of average daily consumption between groups. The superscript letters on the $P$ values correspond to the statistical tests applied, according to the variable’s behaviour: $\lambda$ indicates non-parametric behaviour and the use of Mann-Whitney test, whereas $\psi$ indicates the variables presented normal distribution and the use of Student's $t$ test.

$\S$ Value obtained from the energy from macronutrients recommended for the age group.

Vue obtained from $30 \%$ of the VET calculated for the age group.

II There is no DRI established for dietary fibre and Na for group A. 
Table 5. Comparison of the average daily amount of nutrients served and consumed by age group

\begin{tabular}{|c|c|c|c|c|c|c|}
\hline \multirow[b]{2}{*}{$\begin{array}{l}\text { Analysed } \\
\text { parameter }\end{array}$} & \multicolumn{3}{|c|}{ Group A (7-11 months) } & \multicolumn{3}{|c|}{ Group B (12-36 months) } \\
\hline & $\begin{array}{l}\text { Average daily amount } \\
\text { served }(20 \mathrm{~d})\end{array}$ & $\begin{array}{l}\text { Average daily amount } \\
\text { consumed }(20 \mathrm{~d})\end{array}$ & $P$ & $\begin{array}{l}\text { Average daily amount } \\
\text { served }(20 \mathrm{~d})\end{array}$ & $\begin{array}{l}\text { Average daily amount } \\
\text { consumed }(20 \mathrm{~d})\end{array}$ & $P$ \\
\hline Energy (kJ/kcal) & $2348 \cdot 35 / 561 \cdot 27$ & $1806 \cdot 15 / 431 \cdot 68$ & $0.002^{*}$ & $2448 \cdot 27 / 585 \cdot 18$ & $1827 \cdot 19 / 436 \cdot 71$ & $<0.001^{*}$ \\
\hline Carbohydrates (g) & 99.32 & 76.85 & $0.030 \dagger$ & 100.96 & $76 \cdot 25$ & $<0.001 \dagger$ \\
\hline Proteins $(\mathrm{g})$ & $23 \cdot 28$ & $17 \cdot 70$ & $0.018 \dagger$ & 24.03 & 17.76 & $0.001 \dagger$ \\
\hline Lipids (g) & 7.87 & 5.94 & $0.065 \dagger$ & 9.47 & $6 \cdot 74$ & $0.007 \dagger$ \\
\hline Dietary fibre $(\mathrm{g})$ & $10 \cdot 41$ & 7.82 & $0.105 \dagger$ & 10.09 & 7.50 & $0.063 \dagger$ \\
\hline $\mathrm{Na}(\mathrm{mg})$ & 1261.92 & 959.51 & $0.020 \dagger$ & 1251.00 & $919 \cdot 73$ & $<0.000 \dagger$ \\
\hline $\mathrm{Ca}(\mathrm{mg})$ & $497 \cdot 76$ & $384 \cdot 33$ & $0.110^{*}$ & 497.02 & 379.95 & $0.088^{*}$ \\
\hline $\mathrm{Fe}(\mathrm{mg})$ & $2 \cdot 35$ & 1.84 & $0.105^{\star}$ & $2 \cdot 26$ & 1.74 & $0.074^{*}$ \\
\hline
\end{tabular}

* Non-parametric behaviour and the use of Mann-Whitney test.

† Normal distribution and the use of Student's $t$ test.

\section{Discussion}

\section{School meals and the National School Feeding Program}

No statistically significant difference was found between the evaluated age groups regarding schools meal portions sizes and nutritional composition. Menu composition was the same for both groups for $95 \%$ of the meals ( $n$ 114), even though the nutritional needs of group B (12-36 months) are greater than those of group A (7-11 months), and PNAE's directives ${ }^{(6)}$ establish that meals must be adequate to the needs of each age group.

Meals offered to children in group A presented higher amounts of energy and carbohydrates than those established by the PNAE, possibly due to an excessive consumption of porridge. The dish was a mix of powdered milk, starch (rice, maize and infant wheat cereal) and refined sugar, and was served on all the evaluated days. In contrast, even though group B's nutritional needs were higher than group A's needs, the same nutritional content of energy and carbohydrates was supplied to both groups. Thus, the offer of those nutrients to group B infants did not meet PNAE's minimum standards. This issue could have serious implications on the overall nutritional health of group B children, given the high energetic content offered to group A due to the sugar content in the served tea ( $n$ 19) and the presence of processed food items such as noodles at dinner. In addition, the energetic and nutritional needs of children in their early years are larger than in any other life stage. A research study ${ }^{(24)}$ observed ingestion of high-energy foods by more than $32 \%$ of the evaluated children younger than 2 years, and another study found that soda and processed juices were offered before the child's 1st year to over half of the evaluated children ${ }^{(25)}$. This is a problem not restricted to day-care facilities, and requires recommendations regarding the appropriate nutrition and energy content for children in this life period.

Regarding consumed portions, food consumption of group B children was lower in the second school semester, as the educators began to take the children to have their meals at the school cafeteria, following recommendations established by the Diretriz Municipal de Educação( ${ }^{(26)}$. Thus, children were encouraged to eat by themselves instead of being fed by the educators. This situation was found on $55 \%$ of the days, when a decrease in portion sizes was observed, with consequent enlargement of food waste and failure in meeting group B's nutritional needs. Such a situation could have been less severe if a larger amount of time was available for meal consumption and if there was a closer encouragement of the children during this transition phase.

The offer of lipids was also insufficient for both age groups. This low lipid intake pattern was also observed in household meals intended for breast-fed infants and analysed in laboratory ${ }^{(27)}$. A restriction in adults' intake of fats may be influencing the preparation of children's meals, contrary to what has been recommended by paediatric organisations ${ }^{(28,29)}$, which advise against fat and cholesterol restrictions during the first 2 years of an infant's life. Thus, lipid consumption should provide approximately $30 \%$ of energy intake, which will guarantee adequate consumption and prevent consumed proteins to be used for energy production. Fat ingestion is linked to satiation and represents an essential source of energy and liposoluble vitamins, as well as essential fatty acids used in the synthesis of long-chain unsaturated fatty acids ${ }^{(20)}$.

The offered protein and $\mathrm{Ca}$ contents followed PNAE's recommendations for both age groups. For those nutrients, the observed adequacy may have occurred because of a high frequency of porridge and other milk-based preparations, as milk is a protein- and Ca-rich ingredient. Milk-based meals were offered every day at least at breakfast. In $13 \mathrm{~d}$ (65\%), children consumed milk-based meals in their morning snack (yogurt) or afternoon snack (porridge, sweetened powdered milk, powdered milk with addition of sugar, powdered chocolate and sweet rice). Although the protein content was above the recommended value, a more concerning issue was the $\mathrm{Fe}$ content for both groups. It did not comply with PNAE's recommended minimum value, and consumption of organ meats (such as liver and kidney) was not observed. Beef meats were offered in small portion sizes, and thus were inadequate for children of both age groups. This food item provides great quantities of $\mathrm{Fe}$ of high bioavailability. Furthermore, a substantial offer of milk and milk-based items was found, which are products with a low Fe content ${ }^{(30)}$, and when ingested in excess could interfere with the absorption of Fe content from other food items because of its interaction with $\mathrm{Ca}^{(31)}$.

The small supply of fruits and vegetables on the menu resulted in non-compliance of the offered amount of dietary 
fibre with the Program's reference values ${ }^{(41)}$. This is possibly due to the supply of approximately $115 \mathrm{~g}$ of fruits and $50 \mathrm{~g}$ of vegetables/child per week, not reaching PNAE's recommended minimum of $200 \mathrm{~g} /$ student per week. Information on dietary fibre consumption for children under 2 years of age is scarce ${ }^{(20)}$. A limited ingestion of fruits and vegetables by children is attested by recent Brazilian studies ${ }^{(32-34)}$; one study ${ }^{(32)}$ indicates that early feeding practices, parental education, family income and consumption of high sugar content beverages at 12-16 months are the main explanatory factors. Unfortunately, a similar situation was reported by research studies more than a decade ago in Brazil. Since 2001, these studies ${ }^{(35)}$ reveal a restricted consumption of fruits and vegetables in children in day-care institutions, circumstances also confirmed by additional studies in $2003^{(36)}, 2005^{(37)}$ and $2006^{(38)}$. Recent stu$\operatorname{dies}^{(39,40)}$ involving adolescents have likewise reported this reality, demonstrating that this is a persistent issue throughout the years in this population.

The Brazilian legislation that establishes standardised parameters for school feeding has been continuously updated ${ }^{(6,41)}$; however, such alterations have shown little impact in improving compliance with the established goals, considering the reduced consumption of fruits and vegetables that was observed in the cited work. The inefficiency of school feeding policies is not restricted to Brazil's context and has been reported in other countries as well. A research study ${ }^{(42)}$ based in Los Angeles (USA) found that government policies have been ineffective in reducing the evaluated children's BMI, possibly due to a lack of regulations of meal content outside of school grounds. The authors observed, however, a significant decrease in soda and fried foods consumption at school. Thus, we must not simply criticise non-compliance with government school feeding regulations or the school's and family's role in producing healthy eating habits, but attempt to motivate communication between school and families, in order to provoke changes in the children's and adolescents eating habits, as well as the government recommendations. Therefore, we hope to find studies with a modified situation in the next decade.

One result that stands out is with regard to $\mathrm{Na}$ content found in the meals of both groups. Despite $\mathrm{Na}$ content in foods having met the values recommended by the PNAE (maximum $1400 \mathrm{mg} / \mathrm{d}$ ), this reference value needs further consideration. A previous legislation ${ }^{(41)}$ recommended a $\mathrm{Na}$ level of up to $400 \mathrm{mg} / \mathrm{d}$, which is currently considered adequate for a single meal $^{(6)}$, reaching a level of $1400 \mathrm{mg} \mathrm{Na} / \mathrm{d}$ for three or more meals per day in both age groups. Any full-time student may be provided up to $1400 \mathrm{mg}$ of $\mathrm{Na} / \mathrm{d}$, whether an infant or adolescent. No tolerable upper intake limit (UL) has been established for children under 1 year of age, and the WHO recommends that salt may not be added to these children's food ${ }^{(43)}$. Therefore, PNAE's reference values need to be revised, for they should determine a maximum $\mathrm{Na}$ intake of $1050 \mathrm{mg} / \mathrm{d}$ for children under 36 months of age, which represents $70 \%$ of the UL for children of 1-3 years, as indicated by the IOM ${ }^{(20)}$.

An aggravating factor regarding the amounts of $\mathrm{Na}$ in meals from the studied day-care centres was the offer of dishes and processed products with high $\mathrm{Na}$ content. The presence of noodles and biscuits with high-fat content is contrary to PNAE's guidelines on healthy eating ${ }^{(6)}$ and corroborates other studies $^{(44)}$, which indicate that the high Na offered in schools has become a public school health problem, and therefore requires the government's attention. These findings are even more relevant when noting an increase in blood pressure caused by high $\mathrm{Na}$ intake, predisposition to chronic diseases in this age group and during adult life ${ }^{(45,46)}$. Thus, the offer of meals with high $\mathrm{Na}$ content in a school environment can contribute to acquiring poor eating habits and the development of diseases, especially due to an increased consumption of processed foods, presented by the Consumer Expenditure Survey ${ }^{(47)}$.

\section{School meals and dietary reference intakes}

Assessment of nutritional composition of the consumed meals showed no statistically significant difference between age groups. The amount of carbohydrates actually consumed met $70 \%$ of the DRI in both groups. However, energy value reached only $62 \%$ of the daily needs of children in group A (7-11 months), most likely due to a small supply of lipids and the types of energetic foods consumed by the children, as discussed earlier in this article.

Low intake of lipids in both age groups contributed to a negative impact in the amount of energy supplied to the children. These are concerning results as lipid consumption is essential for obtaining energy and absorption of fat-soluble vitamins and PUFA. However, previous studies with children of the same age range have found the same pattern of food consumption in educational institutions and households ${ }^{(48,49)}$. As care for children up to 3 years of age is crucial for their health throughout their life, because of its effects on physical and cognitive development ${ }^{(2,5)}$, the school feeding programme must guarantee adequate intake of lipids for children's proper neurological development. An increase in the offer of lipids in school meals is needed, as this nutrient's recommended daily intake value for children of $1-3$ years of age is $30-40 \%$ of the total energetic value, which is higher than the percentage recommended for adults ${ }^{(20)}$

Consumed amounts of protein exceeded by $60 \%$ for group A and $36 \%$ for group $\mathrm{B}$ of the daily nutritional requirements. Official agencies stress the importance of adequate protein intake during infancy in order to prevent malnutrition and ensure children's proper growth and development ${ }^{(5)}$. However, high rates of protein consumption can lead to the overloading of the kidneys and liver, loss of $\mathrm{Ca}$ in urine and obesity, becoming the source of health complications ${ }^{(49-51)}$. When an even distribution of macronutrients according to energy values is found, a high protein diet may prevent malnutrition. However, in the case of low lipid intake, as found in this study, proteins may be diverted as a source of energy, which could affect the children's growth and development ${ }^{(52,53)}$.

Recommended DRI values for dietary fibre and $\mathrm{Na}$ for group A's age range are non-existent, due to a lack of conclusive studies $^{(20,21)}$. For group $\mathrm{B}$, consumption of dietary fibre was lower than $50 \%$ of the DRI value, which can be explained by the low consumption of fruits and vegetables. $\mathrm{Na}$ content corresponded to $61 \%$ of the recommended value, which is in line with DRI's and PNAE's appointed values, that is, 
Na content must be at most $70 \%$ or $1050 \mathrm{mg} / \mathrm{d}$. However, as these results have not been investigated in household consumption, they could be greater.

Children in group A had a high Ca intake $(147 \cdot 8 \%$ of the DRI for the age range) and low Fe content (16.7\% of the DRI for the age group), thus indicating risk of anaemia ${ }^{(29)}$. In contrast, the amounts of $\mathrm{Ca}$ actually consumed by group $\mathrm{B}$ did not reach $70 \%$ of the DRI, even with the frequent offer of milk-based preparations. For group B, Fe was another nutrient that failed to reach $70 \%$ of the DRI. Unlike other nutrients, Fe intake decreased with age when the two groups were compared. Even so, the meals consumed by group B did not provide $70 \%$ of the DRI, a concerning factor in the development of anaemia and cognitive impairment of the individuals.

The PNAE determines instructions for the whole country, and thus does not take into account local differences in dietary habits. Hence, one limitation of this study is that results cannot be extended to the entire nation. The number of schools investigated in this study, although limited because of laboratory analyses' high costs and execution times, has been selected to meet rigorous criteria for statistical design and number of enrolled students according to the city regions. Positive aspects of this study include the period of sampling and laboratory analysis of all meals daily consumed for 4 consecutive weeks and covering the quarterly menu of the municipality. In addition, the results from the chemical analysis of meals through the direct weighing of served and consumed portions are more reliable and represent the actual food consumption, besides comparing them with the specific guidelines of the PNAE and the DRI.

Although a statistically significant difference was not observed between nutrients and their recommended values, an important difference was found when served and consumed amounts were compared for carbohydrates, proteins, lipids, energy and $\mathrm{Na}$, which was likely caused by the high rates of food waste found. Actions need to be taken by the day-care centres in order to minimise such waste, so that children consume the whole food portion offered by the schools.

In conclusion, school feeding programmes in the evaluated municipal day-care centres partially met the PNAE guidelines and nutritional needs of their children, with better results for the age group 7-11 months (group A). The small supply of lipids and $\mathrm{Fe}$ and the high intake of simple carbohydrates decrease the quality of food intake and compromise the premises established by the PNAE. Corrective actions need to be employed in order to improve the quality of the meals and meet the nutritional recommendations for each age group.

\section{Acknowledgements}

The authors acknowledge the Department of Education, Culture and Sport of Colombo, Paraná, Brazil, for authorising sample collection at the day-care centres participating in this study.

The article is part of the first author's Master's dissertation and was funded by CNPq process no. 552448/2011-7. The funding agencies had no role in the design and analysis of the study or in the writing of this article.

The authors' contributions are as follows: A. R. worked in all stages of the research, such as project design, analysis and interpretation of the data and writing of the manuscript; A. R. and D. L. F. S. worked on data collection and the laboratory analysis. S. M. S. proofread the manuscript; M. A. O. A. and S. M. R. F. guided all steps of the research, such as project design, collection, analysis and interpretation of the data, manuscript idealisation and revision of the final text. All the authors read and approved the final version of the manuscript.

The authors declare that there are no conflicts of interest.

\section{References}

1. Chauhan A (2015) Plates for slates: the impact of a school feeding programme on community representations of schools. Int J Educ Dev 41, 292-300.

2. Melhuish E (2013) Longer-term effects of early childhood education \& care: evidence and policy. Cad Pesqui 43, 124-149.

3. National Institute for Educational Studies and Research "Anísio Teixeira" (2016) Preliminary Results of the School Census 2013-Colombo (Resultados Premilinares do Censo Escolar 2013-Colombo). Brasília: INEP. http://portal.inep.gov.br/ basica-censo (accessed April 2016).

4. Abizaki A, Buxton C, Kwara L, et al. (2014) School feeding contributes to micronutrient adequacy of Ghanian schoolchildren. Br J Nutr 112, 1019-1033.

5. World Food Programme (2013) State of School Feeding Worldwide. Rome: WFP. http://goo.gl/zdDxed (accessed June 2015).

6. Brazil Ministry of Education and Culture (2013) Resolution no. 26, About School Feeding of Basic Education in the Context of Brazilian School Feeding Program (Programa Nacional de Alimentação Escolar). Brasília: MEC. https:// goo.gl/V4wn0O (accessed June 2015).

7. Sonnino R, Torres CL \& Schneider S (2014) Reflexive governance for food security: the example of school feeding in Brazil. J Rural Stud 36, 1-12.

8. Falcão Gomes RC, Costa THM \& Schmitz BAS (2010) Dietary assessment of pre-school children from Federal District Brazil. Arch Latinoam Nutr 60, 168-174.

9. Longo-Silva G, Toloni MH, Goulart RMM, et al. (2012) Evaluation of food consumption at public day care centers in São Paulo, Brazil. Rev Paul Pediatr 30, 35-41.

10. Fung C, Mcisaac JD, Kuhle S, et al. (2013) The impact of a population-level school food and nutrition policy on dietary intake and body weights of Canadian children. Prev Med 57, 934-940.

11. Lee Y \& Oh YJ (2005) A study on kindergarten's meal service program and children's food intake. Korean J Nutr 38, 232-241.

12. Williams PA, Cates SC, Blitstein JT, et al. (2014) Nutritioneducation program improves preschoolers' at-home diet: a group randomized trial. J Acad Nutr Diet 114, 1001-1008.

13. Durão C, Andreozzi V, Oliveira A, et al. (2015) Maternal child-feeding practices and dietary inadequacy of 4-year-old children. Appetite 92, 15-23.

14. Association of Official Analytical Chemists (AOAC) International (2000) Official Methods of Analysis of AOAC International. Rockville, MD: AOAC International.

15. Padovani RM, Lima DM, Colugnati FAB, et al. (2007) Comparison of proximate, mineral and vitamin composition of common Brazilian and US foods. J Food Compost Anal 20, 733-738.

16. Adolfo Lutz Institute (2008) Physico-Chemical Methods for Food Analysis. São Paulo: IAL. http://goo.gl/97BJBa (accessed June 2015). 
17. Rodrigo CPS \& Bartrina JA (1995) Diário O registro dietético: métodos de doble pesada (Food diaries or dietary records: double food weighting records). In Nutricion $Y$ Salud Publica; Métodos, Bases Científicas Y Aplicaciones (Nutrition and Public Health: Methods, Scientific Bases and Applications) pp. 107-119 [LS Majem, JA Bartrina and JM Verdú, editors]. Barcelona: Masson.

18. Osborne DR \& Voog P (1978) The Analysis of Nutrient in Foods. London: Academic Press.

19. Institute of Medicine (2001) Dietary Reference Intakes for Vitamin A, Vitamin K, Arsenic, Boron, Chromium, Copper, Iodine, Iron, Manganese, Molybdenum, Nickel, Silicon, Vanadium, and Zinc. Washington, DC: National Academies Press.

20. Institute of Medicine (2002-2005) Dietary Reference Intakes for Energy, Carbohydrate, Fiber, Fat, Fatty Acids, Cholesterol, Protein, and Amino Acids. Washington, DC: National Academies Press.

21. Institute of Medicine (2005) Dietary Reference Intakes for Water, Potassium, Sodium, Chlorids, and Sulfate. Washington, DC: National Academies Press

22. Institute of Medicine (2011) Dietary Reference Intakes for Calcium, and Vitamin D. Washington, DC: National Academies Press.

23. IBM Corp. (2010) IBM SPSS Statistics for Windows, Version 19.0. Armonk, NY: IBM Corp.

24. Vilela S, Oliveira A, Pinto E, et al. (2015) The influence of socioeconomic factors and family context on energy-dense food consumption among 2-year-old children. Eur J Clin Nutr 69, 47-54.

25. Longo-Silva G, Toloni MHA, Menezes RCE, et al. (2015) Introduction of soft drinks and processed juice in the diet of infants attending public day care centers. Rev Paul Pediatr 33, 34-41.

26. Colombo Municipal Education Department (2012) Municipal Education Guideline for Childhood Education and Elementary School. Colombo: Municipal Education Department. http://goo.gl/BU5T5T (accessed June 2015).

27. Weber ML \& Morais TB (2010) Nutritional composition, assessed by chemical analyses, of prepared foods available for primary-school children: a comparison of public and private schools. Public Health Nutr 13, 1855-1862.

28. Kleinman RE (editor) (2009) Pediatric Nutrition Handbook, 6th ed. Elk Grove Village, IL: American Academy of Pediatrics.

29. Brazilian Society of Pediatrics (2012) Infant, Preschooler, Scholar, and Adolescent Feeding Guideline, 3rd ed. Rio de Janeiro: SBP.

30. World Health Organization (2009) Infant and Young Child Feeding: Model Chapter for Textbooks for Medical Students and Allied Health Professionals. Geneva: WHO.

31. World Health Organization (2008) Worldwide Prevalence of Anaemia 1993-2005: WHO Global Database on Anaemia. Geneva: WHO.

32. Valmórbida JL \& Vitolo MR (2014) Factors associated with low consumption of fruits and vegetables by preschoolers of low socio-economic level. J Pediatr 90, 464-471.

33. Costa LCF, Vasconcelos FAG \& Corso AC (2012) Factors associated with adequate fruit and vegetable intake by school children in Santa Catarina State, Brazil. Cad Saude Publica $\mathbf{2 8}$, 1133-1142.

34. Pedraza DF, Queiroz D \& Gama JSFA (2015) Evaluation of food consumption among Brazilian children attending daycare centers: a systematic review. Rev Bras Saude Mater Infant 15, 17-31.
35. Cruz GF, Santos RS, Carvalho CMRG, et al. (2001) Dietetic evaluation in municipal dietetic evaluation in municipal day-care centers in Teresina, Piauí, Brazil. Rev Nutr 14, 21-32.

36. Spinelli MGN, Goulart RMM, Santos ALP, et al. (2003) Six to eighteen-month-old children's food intake in day-care centers. Rev Nutr 16, 409-441.

37. Castro TG, Novaes JF, Silva MR, et al. (2005) Characteristics of dietary intake, socioeconomic environment and nutritional status of preschoolers at public kindergartens. Rev Nutr 18, 321-330.

38. Barbosa RMS, Carvalho CGN, Franco VC, et al. (2006) Food intake assessment of children attending a philanthropic daycare center in the Ilha de Paqueta, Rio de Janeiro, Brazil. Rev Bras Saude Matern Infant 6, 127-134.

39. Muniz LC, Zanini RV, Schneider BC, et al. (2013) Prevalence and factors associated with the consumption of fruit and vegetables by adolescents in public schools in Caruaru, Pernambuco. Cienc Saude Colet 18, 393-404.

40. Monticelli FDB, Souza JMP \& Souza SB (2013) Adolescent students' consumption of fruit, greens and vegetables. J Hum Growth Develop 23, 1-7.

41. Brazil Ministry of Education and Culture (2009) Resolution no. 38, About School Feeding of Basic Education in the Context of Brazilian School Feeding Program (Programa Nacional de Alimentação Escolar). Brasília: MEC. https://goo.gl/cVtj8C (accessed June 2015).

42. Bauhoff S (2014) The effect of school district nutrition policies on dietary intake and overweight: a synthetic control approach. Econ Hum Biol 12, 45-55.

43. World Health Organization (2002) Complementary Feeding. Report of the Global Consultation: Summary of Guiding Principles. Geneva: WHO.

44. Portella MB, Morais TB \& Morais MB (2010) Excess sodium and insufficient iron content in complementary foods. J Pediatr (Rio J) 86, 303-310.

45. World Health Organization (2004) Global Strategy on Diet, Physical Activity and Health. Geneva: WHO.

46. Brazil National Health Surveillance Agency (2010) Nutritional Profile of Processed Foods, Technical Report no. 42. Brasília: ANVISA.

47. Brazilian Institute of Geography and Statistics - IBGE (2011) Household Budget Research 2008-2009: Individual Analysis of Food Intake in Brazil. Rio de Janeiro: IBGE.

48. American Heart Association (2013) Dietary Recommendations For Healthy Children. Dallas, TX: AHA. http://goo.gl/xSO0xA (accessed June 2015).

49. Gray B, Reyes MC \& Conners LL (2013) How much milk is too much? A case study of an obese toddler. J Pediatr Health Care 27, 148-154.

50. International Life Sciences Institute (2009) Dietary Reference Intakes. São Paulo: ILSI.

51. Diethelm K, Günther ALB, Schulze MB, et al. (2014) Prospective relevance of dietary patterns at the beginning and during the course of primary school to the development of body composition. Br J Nutr 111, 1488-1498.

52. Bonotto GM, Schneider BC, Santos IS, et al. (2012) Adequacy of energy consumption and macronutrients of children under six years of age. Rev Paul Pediatr 30, 513-519.

53. Brenner BM, Meyer TW \& Hostetter TH (1982) Dietary protein intake and the progressive nature of kidney disease. $N$ Engl $J$ Med 307, 652-659. 